\title{
RESISTENSI ISOLAT VIBRIO DARI BEBERAPA PANTI BENIH UDANG WINDU (Penaeus monodon) TERHADAP ANTIBIOTIK
}

\author{
Zafran*), Des Roza*) dan Isti Koesharyani*)
}

\begin{abstract}
ABSTRAK
Uji konsentrasi hambat terendah Minimal Inhibitory Concentration (MIC) 3 jenis antibiotik, Kloramfenikol (CP), Oksitetrasiklin (OTC), dan Furazolidon (FZ) terhadap 7 bakteri Vibrio yang diisolasi dari larva sakit yang berasal dari panti benih penelitian di Gondol dan panti benih komersial di Bali dan Jawa Timur, telah dilakukan di laboratorium penyakit Loka Penelitian Perikanan Pantai di Gondol. Sebagai media uji digunakan pepton broth yang mengandung $1 \%$ $\mathrm{NaCl}$. Hasil pengujian menunjukkan bahwa bakteri Vibrio yang diisolasi dari panti benih komersial ternyata lebih resisten terhadap ketiga antibiotik uji dibanding Vibrio yang diisolasi dari panti benih penelitian di Gondol. Nilai MIC antibiotik CP, OTC, dan FZ terhadap Vibrio yang diisolasi dari panti benih penelitian Gondol berkisar dari 1,9-7,8 ppm, sedang untuk Vibrio yang diisolasi dari panti benih komersial $>15 \mathrm{ppm}$. Pemakaian antibiotik secara rutin sebagaimana yang diterapkan oleh panti benih komersial tampaknya telah menyebabkan munculnya strain Vibrio yang resisten terhadap antibiotik.
\end{abstract}

\section{ABSTRACT: Resistance of vibrios isolated from infected Penaeus monodon to} antibiotics. By: Zafran, Des Roza, and Isti Koesharyani.

In vitro activity of three chemotherapeutants, Chloramphenicol (CP), Oxytetracycline (OTC), and Furazolidone (FZ) against 7 isolates of Vibrio bacteria isolated from infected shrimp (Penaeus monodon) larvae, sampled from Gondol research hatchery and commercial shrimp hatcheries in Bali and East Java, were tested for their Minimal Inhibitory Concentration (MIC) using a serial dilution methods in pepton broth with $1 \% \mathrm{NaCl}$. The vibrios isolated from commercial hatcheries were more resistant to chemotherapeutants compared to those isolated from Gondol research hatchery. The MIC values of $C P, O T C$, and $\mathrm{FZ}$ were $>15 \mathrm{ppm}$ for all of the three vibrios isolates from commercial hatcheries, and 1.9-7.8 ppm for those from the hatchery of Gondol Research Station. The routine use of chemotherapeutants in commercial hatcheries is suspected to cause the development of antibiotic resistant strains of vibrios.

KEYWORDS: Chemotherapeutant, antibiotics, Penaeus monodon, Vibrio bacteria.

\section{PENDAHULUAN}

Vibriosis merupakan kendala utama yang dihadapi para pengelola panti benih udang windu di Indonesia. Dua jenis penyakit yang disebabkan oleh bakteri Vibrio yang sudah terungkap adalah penyebab penyakit udang menyala (Sunaryanto dan Mariam, 1986; Baticados et al., 1990; LavillaPitogo et al., 1992a; Rukyani et al., 1992; Zafran, 1992; Zafran et al., 1994; Zafran dan Roza, 1993) dan udang bengkok (Sunaryanto et al., 1987).

Pemakaian antibiotik merupakan pilihan yang umum diambil oleh para praktisi panti benih dalam upaya mencegah dan menanggulangi infeksi Vibrio. Hanya saja upaya tersebut sering tidak berhasil karena pemilihan jenis dan dosis obat yang tidak tepat sehingga tidak efektif dalam mengatasi infeksi Vibrio. Selain itu, diduga bakteri Vibrio yang hidup di lingkungan panti benih komersial sudah resisten terhadap antibiotik yang sudah rutin digunakan.

Sehubungan dengan permasalahan di atas, perlu dilakukan uji efektivitas antibiotik yang umum digunakan di panti benih komersial dalam mengatasi vibriosis. Sebagai pembanding digunakan bakteri Vibrio yang diisolasi dari panti benih udang windu Lolitkanta Gondol, di mana penggunaan antibiotik sangat dihindari.

*) Peneliti pada Loka Penelitian Perikanan Pantai Gondol, Bali 


\section{BAHAN DAN METODE}

Antibiotik yang digunakan adalah Kloramfenikol (CP), Oksitetrasiklin (OTC), dan Furazolidon (FZ). Antibiotik tersebut dipilih karena umum digunakan di panti-panti benih. Sedangkan isolat yang digunakan tercantum dalam Tabel 1. Semua bakteri uji diremajakan terus pada media Marine Agar (MA) dan diinkubasi pada suhu $25^{\circ} \mathrm{C}$. Sebagai media pengujian di. gunakan larutan pepton $1 \%$ yang mengandung $\mathrm{NaCl} 1 \%$.

Dosis masing masing antibiotik dibuat melalui metode pengenceran dua kali dalam larutan pepton yang mengandung $1 \% \mathrm{NaCl}$. Metode pengenceran dua kali umum digunakan untuk uji MIC (Ruangpan \& Kitao, 1992). Sampai sekarang belum ada standar baku untuk kisaran konsen. trasi obat dalam uji MIC (Lightner, 1996), sehingga dalam percobaan ini diambil kisaran antara 0,1-500 ppm. Pada langkah pertama disiapkan 13 buah tabung reaksi. Tabung pertama dibiarkan kosong, sedang tabung ke-2 sampai ke13 diisi dengan larutan pepton yang mengandung $1 \% \mathrm{NaCl}$ masing-masing $5 \mathrm{~mL}$. Pada langkah ke2, ke dalam Erlenmeyer yang sudah diisi larutan pepton yang mengandung $1 \% \mathrm{NaCl}$ ditambahkan antibiotik uji sehingga dicapai konsentrasi 500 ppm. Dari larutan pepton yang sudah mengandung $500 \mathrm{ppm}$ antibiotik uji ini diambil masing-masing $5 \mathrm{~mL}$ dan dimasukkan ke dalam tabung reaksi nomor 1 dan 2 . Tabung reaksi pertama, dengan demikian akan berisi $5 \mathrm{~mL}$ pepton dengan konsentrasi antibiotik $250 \mathrm{ppm}$. Dari tabung reaksi ke-2 selanjutnya diambil $5 \mathrm{~mL}$ dan dimasukkan ke dalam tabung reaksi nomor 3 dan seterusnya sampai tabung rekasi nomor 13 . Kelebihan $5 \mathrm{~mL}$ pada tabung reaksi ke-13 dibuang sehingga volume setiap tabung reaksi sama-sama $5 \mathrm{~mL}$. Dengan cara demikian konsentrasi akhir antibiotik uji dalam ketigabelas tabung reaksi adalah $500 ; 250 ; 125 ; 62,5 ; 31,3$; 15,$6 ; 7,8 ; 3,9 ; 1,9 ; 1,0 ; 0,5 ; 0,2$ dan 0,1 ppm. Ke dalam tabung reaksi kemudian diinokulasikan suspensi bakteri uji (setara dengan McFarland Equivalence Turbidity Standard 1.0) masingmasing satu ose. Semua proses di atas dilakukan dalam clean bench sehingga tidak terjadi kontaminasi. Setiap perlakuan diulang sebanyak $3 \mathrm{kali}$. Dalam penelitian ini juga digunakan $5 \mathrm{~mL}$ pepton yang mengandung $1 \% \mathrm{NaCl}$ yang tidak diinokulasi bakteri uji sebagai kontrol negatif dan $5 \mathrm{ml}$

Tabel 1. Isolat Vibrio yang digunakan dalam penelitian.

Table 1. Isolates of Vibrio used in the experiment.

\begin{tabular}{clll}
\hline $\begin{array}{c}\text { Isolat } \\
\text { Isolate }\end{array}$ & $\begin{array}{c}\text { Strain } \\
\text { Strain }\end{array}$ & \multicolumn{1}{c}{$\begin{array}{c}\text { Sumber } \\
\text { Sources }\end{array}$} & \multicolumn{1}{c}{$\begin{array}{c}\text { Lokasi } \\
\text { Location }\end{array}$} \\
\hline A & Vibrio sp. & $\begin{array}{l}\text { PL-3 terinfeksi dengan Vibrio } \\
\text { PL-3 infected with Vibrio }\end{array}$ & $\begin{array}{l}\text { Panti benih komersial (Bali) } \\
\text { Commercial hatchery (Bali) }\end{array}$ \\
B & Vibrio sp. & $\begin{array}{l}\text { PL-3 terinfeksi dengan Vibrio } \\
\text { PL-3 infected with Vibrio }\end{array}$ & $\begin{array}{l}\text { Panti benih komersial (Bali) } \\
\text { Commercial hatchery (Bali) }\end{array}$ \\
C & Vibrio sp. & $\begin{array}{l}\text { Dasar bak dengan bercak merah } \\
\text { Rearing tank bottom with red spot }\end{array}$ & $\begin{array}{l}\text { Panti benih Lolitkanta Gondol (Bali) } \\
\text { Gondol Research Station hatchery (Bali) }\end{array}$ \\
D & V. harveyi & $\begin{array}{l}\text { Mysis terinfeksi dengan Vibrio bercahaya } \\
\text { Mysis infected with luminescent vibriosis }\end{array}$ & $\begin{array}{l}\text { Panti benih Lolitkanta Gondol (Bali) } \\
\text { Gondol Research Station hatchery (Bali) }\end{array}$ \\
E & V. harveyi & $\begin{array}{l}\text { Mysis terinfeksi dengan Vibrio bercahaya } \\
\text { Mysis infected with luminescent vibriosis }\end{array}$ & $\begin{array}{l}\text { Panti benih Lolitkanta Gondol (Bali) } \\
\text { Gondol Research Station hatchery (Bali) }\end{array}$ \\
F & V. harveyi & $\begin{array}{l}\text { Mysis terinfeksi dengan Vibrio bercahaya } \\
\text { Mysis infected with luminescent vibriosis }\end{array}$ & $\begin{array}{l}\text { Panti benih komersial (Banyuwangi) } \\
\text { Commercial hatchery (Banyuwangi) }\end{array}$ \\
G & V.harveyi & $\begin{array}{l}\text { Mysis terinfeksi dengan Vibrio bercahaya } \\
\text { Mysis infected with luminescent vibriosis }\end{array}$ & $\begin{array}{l}\text { Panti benih komersial (Situbondo) } \\
\text { Commercial hatchery (Situbondo) }\end{array}$ \\
\hline
\end{tabular}


pepton yang mengandung $1 \% \quad \mathrm{NaCl}$ yang diinokulasi bakteri sebagai kontrol positif. Media uji selanjutnya diinkubasikan pada suhu $25^{\circ} \mathrm{C}$ selama 24 jam. Nilai MIC dilihat dari dosis terendah masing-masing antibiotik yang dapat menghambat pertumbuhan masing-masing bakteri uji. Bakteri yang tumbuh dapat dibedakan dari yang tidak tumbuh secara visual dengan melihat kejernihan atau kekeruhan media uji, dalam hal ini larutan pepton.

\section{HASIL DAN PEMBAHASAN}

Dari hasil uji terlihat perbedaan nilai MIC yang mencolok antara Vibrio yang diisolasi dari panti benih komersial dibandingkan Vibrio yang diisolasi dari panti benih Lolitkanta Gondol (Tabel 2). Bakteri $V$. harveyi yang diisolasi dari panti benih penelitian Gondol sudah terhambat pertumbuhannya pada dosis 1,9 ppm baik oleh CP maupun OTC dan 1,9-3,9 ppm untuk FZ, sedang $V$. harveyi yang diisolasi dari panti benih komersial di Banyuwangi dan Situbondo, Jawa
Timur, baru dapat terhambat pada dosis lebih dari 15 ppm, baik untuk CP, OTC maupun FZ. Data tersebut menunjukkan bahwa bakteri Vibrio di lingkungan panti benih komersial yang rutin diberi perlakuan antibiotik telah berhasil membentuk resistensi. Karena itu, tidak heran bila ada keluhan para pengelola panti benih bahwa antibiotik yang biasanya efektif mengatasi vibriosis sekarang tidak mempan lagi. Aoki (1974) menyatakan bahwa penggunaan antibiotik yang terlalu sering dapat menyebabkan resistensi bagi populasi bakteri melalui proses transfer "Rplasmid" yang terdapat dalam DNA bakteri. Selain transfer antar individu melalui proses konyugasi, R-plasmid juga dapat ditransfer pada saat pembelahan sel dimana $R$-plasmid tersebut juga ikut mengalami pembelahan. Gejala resistensi bakteri terhadap antibiotik telah banyak dilaporkan, antara lain oleh Ruangpan dan Kitao (1992) terhadap bakteri yang diisolasi dari udang windu di Thailand dan Aoki (1992) terhadap ikanikan di Jepang. Penelitian tentang gejala ini juga telah dilakukan oleh Baticados dan Paclibare (1992) di Filipina.

Tabel 2. Nilai konsentrasi hambat terendah tiga jenis antibiotik terhadap 7 isolat Vibrio yang diisolasi dari larva Penaeus monodon.

Table 2. MIC values of three chemotherapeutants against 7 isolates of Vibrio isolated from infected shrimp Penaeus monodon larvae.

\begin{tabular}{|c|c|c|c|c|c|}
\hline \multirow{2}{*}{\multicolumn{2}{|c|}{$\begin{array}{l}\text { Isolat } \\
\text { Isolate }\end{array}$}} & \multirow{2}{*}{$\begin{array}{l}\text { Asal } \\
\text { Origin }\end{array}$} & \multicolumn{3}{|c|}{ Konsentrasi hambat terendah (MIC) (ppm) } \\
\hline & & & $\mathbf{C P}$ & OTC & FZ \\
\hline A. & Vibrio sp. & $\begin{array}{l}\text { Panti benih komersial (Bali) } \\
\text { Commercial hatchery. (Bali) }\end{array}$ & 62.5 & 31.3 & 15.6 \\
\hline B. & Vibrio sp. & $\begin{array}{l}\text { Panti benih komersial (Bali) } \\
\text { Commercial hatchery (Bali) }\end{array}$ & 62.5 & 62.5 & 31.3 \\
\hline C. & Vibrio sp. & $\begin{array}{l}\text { Panti benih Lolitkanta Gondol (Bali) } \\
\text { Gondol Research Station hatchery (Bali) }\end{array}$ & 3.9 & 3.9 & 7.8 \\
\hline D. & $V$. harveyi & $\begin{array}{l}\text { Panti benih Lolitkanta Gondol (Bali) } \\
\text { Gondol Research Station hatchery (Bali) }\end{array}$ & 1.9 & 1.9 & 1.9 \\
\hline E. & V. harveyi & $\begin{array}{l}\text { Panti benih Lolitkanta Gondol (Bali) } \\
\text { Gondol Research Station hatchery (Bali) }\end{array}$ & 1.9 & 1.9 & 3.9 \\
\hline F. & V. harveyi & $\begin{array}{l}\text { Panti benih komersial (Bali) } \\
\text { Commercial hatchery (Banyuwangi) }\end{array}$ & 15.6 & 15.6 & 31.3 \\
\hline G. & V. harveyi & $\begin{array}{l}\text { Panti benih komersial (Situbondo) } \\
\text { Commercial hatchery (Situbondo) }\end{array}$ & 15.6 & 31.3 & 15.6 \\
\hline $\begin{array}{l}\text { CP } \\
\text { OTC } \\
\text { FZ }\end{array}$ & $\begin{array}{l}=\text { khlor } \\
=\text { oksite } \\
=\text { furazo }\end{array}$ & $\begin{array}{l}\text { fenicol (chloramphenicol) } \\
\text { siklin (oxytetracycline) } \\
\text { lon (furozolidone) }\end{array}$ & & & \\
\hline
\end{tabular}


Mengingat begitu cepatnya bakteri mampu membentuk resistensi terhadap antibiotik, maka sudah saatnya penggunaan antibiotik sedapat mungkin dihindari. Kalaupun antibiotik tetap digunakan, hendaknya dipilih antibiotik yang bersifat membunuh bakteri (baktericidal) dan digunakannya harus tepat dosis. Kloramfenikol maupun tetrasiklin adalah 2 jenis antibiotik yang tidak mempunyai efek membunuh terhadap bakteri dan hanya berperan dalam menghambat sintesis protein yang mana sangat diperlukan dalam perbanyakan dan pembelahan sel bakteri (Herwig, 1979). Efek negatif penggunaan antibiotik ini bukan hanya terhadap perkembangan strain bakteri yang resisten dan patogen bagi udang, tetapi juga terhadap bakteri yang patogen bagi manusia dan hewan peliharaan.

Metode lain yang mungkin dikembangkan dalam upaya mencegah terjadinya infeksi Vibrio adalah dengan mengendalikan populasi bakteri patogen pada batas aman (Zafran dan Roza, 1993) dan pemanfaatan kemampuan diatom dalam menekan populasi bakteri patogen pada air pemeliharaan larva udang windu di panti benih (Lavilla-Pitogo et al., 1992b).

\section{KESIMPULAN DAN SARAN}

Dari hasil penelitian diketahui bahwa bakteri Vibrio yang diisolasi dari panti benih komersial baik dari Gondol (Bali), Banyuwangi, maupun Situbondo (Jawa Timur), lebih resisten terhadap antibiotik Kloramfenikol, Oksitetrasiklin, dan Furazolidone dibandingkan dengan bakteri Vibrio yang diisolasi dari panti benih Lolitkanta Gondol, Bali. Nilai MIC untuk Vibrio yang diisolasi dari panti benih Lolitkanta Gondol berkisar antara 1,9 dan 7,8 ppm untuk ketiga antibiotik uji, sedang untuk Vibrio yang diisolasi dari panti benih komersial berkisar antara 15,6 dan 62,5 ppm.

Mengingat begitu cepatnya bakteri Vibrio mampu membentuk faktor resistensi terhadap antibiotik, maka penggunaan antibiotik secara bebas harus dihindari.

\section{DAFTAR PUSTAKA}

Aoki, T. 1974. Studies of drug resistant bacteria isolated from water of carp ponds and intestinal tracts of carp. Bull. Jap.Soc. Sci. Fish. 40:247-254.

Aoki, T. 1992. Chemotherapy and drug resistance in fish farms in Japan. In M. Shariff, R.P. Subasinghe and J.R. Arthur (Eds.), Diseases in Asian Aquaculture I. Fish Health Section, Asian Fisheries Society, Manila, Philippines. pp.519-529

Baticados, M.C.L., F.R. Cruz-Lacierda, M.C. de la Cruz, R.C. Duremdez-Fernandez, R.R. Gacutan, C.R. Lavilla-Pitogo, and G.D. Lio-Po. 1990. Diseases of penaeid shrimp in the Philippines. Aquaculture Extension Manual No 16, SEAFDEC. $46 \mathrm{p}$.

Baticados, M.C.L. and J.D. Paclibare. 1992. The use of chemotherapeutic agents in aquaculture in the Philippines. In M. Shariff, R.P. Subasinghe and J.R Arthur (Eds.), Diseases in Asian Aquaculture I. Fish Health Sect ion, Asian Fisheries Society, Manila, Philippines. p.531-546

Herwig, N. 1979. Handbook of drugs and chemicals used in the treatment of fish diseases. Charles C. Thomas Publisher. $272 \mathrm{p}$.

Lavilla-Pitogo, C.R., L.C. Albright, M.C. Paner and N.A. Sunaz. 1992a. Studies on the sources of luminescent Vibrio harveyi in Penaeus monodon hatcheries. In M. Shariff, R.P. Subasinghe and J.R. Arthur (Eds.), Diseases in Asian Aquaculture I. Fish Health Section, Asian Fisheries Society, Manila, Philippines. p.157-164

Lavilla-Pitogo, C.R., L.C. Albright, M.C. Paner. 1992b. Survival of luminescent Vibrio harveyi exposed to different physicochemical condition and simulated hatchery situation In Proceeding Third Asian Fisheries Forum, Singapore, 26-30 October 1992.

Lightner, D.V. 1996. A Handbook of shrimp pathology and diagnostic procedures for diseases of cultured penaeid shrimp. The World Aquaculture Society, Louisiana, USA. 220 p.

Ruangpan, L. and T. Kitao. 1992. Minimal Inhibitory Concentration of 19 chemotherapeutantsagainst Vibrio bacteria of shrimp, Penaeus monodon. In M. Shariff, R.P. Suabsinghe and J.R. Arthur (Eds.), Diseases in Asian Aquaculture I. Fish Health Section, Asian Fisheries Society, Manila, Philippines. p.135-142

Rukyani, A., P. Taufik, dan Taukhid. 1992. Penyakit kunang-kunang (luminescent vibriosis) dan cara penanggulangannya di hatchery udang windu. Dalam Prosiding Seminar Sehari Upaya Penanggulangan Penyakit Benur Pada Hatchery Udang, Surabaya, 20 Februari 1992. p.47-60

Sunaryanto, A., and A. Mariam. 1986. Occurrence of pathogenic bacteria causing luminescence in penaeid larvae in Indonesia hatcheries. Bull. Brakckishwater Aqua. Dev. Cent., 8:64-70.

Sunaryanto, A., A. Mariam dan Pujianto. 1987. Penyakit Udang Windu. INFIS Manual Seri No. 43. 
Zafran. 1992. Pencegahan penyakit kunang-kunang pada larva udang windu, Penaeus monodon. Dalam Prosiding Seminar Sehari Upaya Penanggulangan Penyakit Benur Pada Hatchery Udang. Surabaya, 20 Februari 1992. p. 59-61

Zafran dan Des Roza. 1993. Teknik penanggulangan penyakit udang menyala di hatcheri melalui pengendalian populasi bakteri. J. Penel. Budidaya Pantai, 9(2):127-132.

Zafran, Des Roza, K. Sugama, S. Wada, and K. Hatai. 1994. Histological study of luminescent Vibrio harveyi infection in hatchery reared larvae of Penaeus monodon. In Chou et al. (Eds.), Proceeding of the Third Asian Fisheries Forum. Asian Fisheries Society, Manila, Philippines. p: 294-297 